\title{
DUAL FORM OF EDUCATION AS A PROSPECT OF DEVELOPMENT OF UNIVERSITY EDUCATION IN UKRAINE
}

\section{ДУАЛЬНА ФОРМА ЗДОБУТТЯ ОСВІТИ ЯК ПЕРСПЕКТИВА РОЗВИТКУ УНІВЕРСИТЕТСЬКОЇ ОСВІТИ В УКРАЇНІ}

\author{
Olga Yakovchuk ${ }^{1}$ \\ Viktoriia Stoliarenko
}

DOI: https://doi.org/10.30525/978-9934-588-15-0-22

\begin{abstract}
The market of educational services remains one of the most dynamic and innovative social structure, which is related to the resource providing of a manufacturing sector, maintenance and strengthening of intellectual and qualification potential of young specialists. The employment of graduates of educational institutions is an important component of the economic sector of the state and one of the indicators of the qualitative training of young specialists in higher educational establishments. Most employers put high requirements to the level of theoretical knowledge and formation of practical skills of young specialists. Among the problems of employment of graduates of higher educational institutions it is possible to note the discrepancy of quality of education to requirements of employers, lack of practical work experience and developed skills of labor activity. Such peculiarities of labor market situation and employers' requirements to the level of professional training of young specialists cause the necessity of transformations in the system of higher education. In particular: establishing the correlation between the educational process, the level of skills of applicants for higher education and the requirements of employers, improving the training quality of specialists for various sectors of the economy, strengthening the interaction of educational and industrial environment, providing the control over the level of general and professional knowledge of graduates of educational
\end{abstract}

\footnotetext{
${ }^{1}$ Candidate of Pedagogical Sciences, Senior Lecturer of Technologies in the Restaurant Industry and Hotel and Restaurant Business Department, Donetsk National University of Economics and Trade named after Mikhail Tugan-Baranovsky, Ukraine

${ }^{2}$ Candidate of Chemistry Sciences, Lecturer, Kryvyi Rih State Pedagogical University, Ukraine

(C) Olga Yakovchuk, Viktoriia Stoliarenko
} 
institutions by business entities, ensuring the competitiveness of graduates of educational institutions and the implementation of labor potential of young professionals. One of the ways to solve the problem of employment of graduates of educational institutions, improving the level of their practical training, increasing the willingness of future experts to implementation of production functions is the introduction of dual education into the higher school. Such form of the organization of educational process increases the level of activity of students, creates necessary conditions for their self-development, self-organization, occupational orientation, promotes receiving not only theoretical knowledge, but also practical skills. The article considers the essence of the concept of «dual form of education»; analyzes the features of the introduction of dual education into the higher school; describes the most important components, advantages and shortcomings of its implementation. On the basis of the analysis of scientific works it is presented the mechanism of interaction of participants of educational process on dual education forms. Dual education is interpreted as a form of organization of the educational process, which involves the integration of theoretical training of students in institutions of higher education with training in the workplace (on the basis of enterprises, organizations, institutions) in order to acquire practical skills according to their qualification.

\section{1. Ветуп}

Ринок освітніх послуг залишається однієї з найбільш динамічних та інноваційних соціальних ланок, пов'язаної із ресурсним забезпеченням виробничого сектору, збереженням й посиленням інтелектуального та кваліфікаційного потенціалу молодих фахівців.

Працевлаштування випускників навчальних закладів є важливою складовою економічного сектору держави та одним з показників якості підготовки студентів у закладах вищої освіти. Більшість працедавців ставлять високі вимоги до рівня теоретичних знань та сформованості практичних навичок молодих фахівців. Серед проблем працевлаштування випускників закладів вищої освіти можна відзначити невідповідність якості освіти вимогам роботодавців, відсутність практичного досвіду роботи та сформованих навичок трудової діяльності.

Такі особливості кон'юктури ринку праці та вимоги роботодавців до рівня професійної підготовки молодих фахівців викликають необ- 
хідність трансформацій у системі вищої освіти. Зокрема: встановлення відповідності між освітнім процесом, рівнем вмінь, навичок здобувачів вищої освіти та вимогами працедавців, підвищення якості підготовки фахівців для різних галузей народного господарства, посилення взаємодії освітнього та виробничого середовища, контроль за рівнем загальних та професійних знань випускників закладів освіти зі сторони суб'єктів господарювання, забезпечення конкурентоспроможності випускників закладів освіти, реалізація трудового потенціалу молодих фахівців.

Одним 3 шляхів розв'язання проблем працевлаштування випускників закладів освіти, удосконалення рівня їх практичної підготовки, посилення готовності майбутніх фахівців до реалізації виробничих функцій $є$ запровадження дуальної освіти у вищій школі. Сама така форма організації освітнього процесу підвищує рівень активності студентів, створює необхідні умови для їх саморозвитку, самоорганізації, професійної орієнтації, сприяє здобуттю не тільки теоретичних знань, але й практичних вмінь та навичок.

У статті розглянуто сутність поняття «дуальна форма здобуття освіти», проаналізовано особливості реалізації дуальної освіти у вищій школі, схарактеризовано найважливіші компоненти, переваги та недоліки ії запровадження. На основі аналізу наукових праць представлено механізм взаємодії учасників освітнього процесу за дуальної форми здобуття освіти. Дуальна освіта трактується як форма організації освітнього процесу, що передбачає інтеграцію теоретичного навчання студентів у закладах вищої освіти з навчанням на робочих місцях (на базі підприємств, організацій, установ) з метою набуття практичних вмінь та навичок відповідно до кваліфікації.

\section{2. Дуальна освіта як форма взасмодії освіти та виробництва}

Динаміка змін соцільно-економічного розвитку суспільства та державно-політичного устрою країни зумовлює потребу у висококваліфікованих фахівцях, які здатні швидко адаптуватись до умов сучасного виробництва, приймати нестандартні рішення в умовах постійної ринкової конкуренції, володіти професійною мобільністю. Варто погодитись $з$ думкою доктора педагогічних наук Л. Сушенцевою, яка вважає, що сучасна освіти забезпечує можливість кожній людині «оволодівати знаннями, самореалізуватися, самовдосконалюватися» [14]. 
Проблеми динамічних коливань ринку праці та працевлаштування випускників закладів освіти висвітлено у працях багатьох вчених: А. Венгер, В. Герасимчук, В. Гнибіденко, В. Давиденко, Т. Заяць, С. Зінченко, С. Пазюк, А. Сіленко, П. Шевчук та ін. Всі вони відзначають невідповідність освітнього середовища вимогам ринку праці, яка відображається у тому, що значна частина випускників закладів вищої освіти щорічно поповнює лави безробітних.

Згідно даних Державної служби статистики України та адміністративних даних державної служби зайнятості, рівень безробіття серед молоді щороку складає більше 30\% (від загальної кількості безробітних). Зокрема, за січень-серпень 2019 року цей показник досяг $33 \%$. Кількість випускників, що не змогли знайти роботу після закінчення закладів вищої освіти склала 8,6 тис. За означений період послуги державної служби зайнятості загалом отримували 178,7 тис. молодих осіб.

Серед причин низького рівня працевлаштування випускників закладів вищої освіти можна відзначити недосконалість теоретичної підготовки, відсутність практичного досвіду роботи та низький рівень сформованості навичок трудової діяльності. Ринок праці потребує не просто фахівців, що мають певні знання чи вміння, але й висококваліфікованих спеціалістів, здатних до інноваційної діяльності.

За таких умов постає проблема реорганізації системи підготовки майбутніх фахівців, впровадження у навчальний процес нових освітніх моделей, удосконалення механізмів взаємодії освіти та ринку праці. Оскільки, Сучасний працедавець вимагає від фахівців не тільки наявності теоретичних знань, а в першу чергу - вмінь застосовувати набуті знання на практиці, швидко сприймати великі обсяги інформації, знаходити оптимальні шляхи вирішення виробничих завдань.

Незважаючи на високий рівень теоретичних знань випускників закладів вищої освіти України, більшість 3 них мають недостатній рівень сформованості практичних навичок та вмінь. Через відсутність ефективної системи взаємодії «держава - заклад вищої освіти - суб' єкт господарювання» рівень підготовки випускників закладів освіти не завжди відповідає вимогам роботодавців. Це є однією з причин низького рівня працевлаштування випускників після завершення навчання у закладах вищої освіти. 
Науковець Н. Золотарьова відзначає наявний розрив між потребами виробничого середовища у висококваліфікованих кадрах, їх реальною наявністю та відповідністю кваліфікацій молодих фахівців вимогам ринку праці, викликаний недостатньою взаємодією роботодавців та системи освіти [7]. Засобом зменшення розриву науковець визначає узгоджену взаємодію виробничого та освітнього сектора. Суголосною цьому є думка О. Фалалєєва, який обов'язковою умовою гармонізації ринку освітніх послуг та ринку праці вважають реальне залучення роботодавців до процесу навчання [15].

У зв'язку з цим виникає необхідність впровадження дуальної форми здобуття освіти, яка б підвищувала рівень активності студентів, створювала умови для їх професійної орієнтації, саморозвитку, інтегрувала теоретичні знання студентів з практичними вміннями та навичками. У дослідженні Н. Гаріфулліної та К. Мазаєвої відзначається, що для сучасного роботодавця важлива наявність у фахівця сформованих практичних навичок для виконання тих чи інших видів робіт, досвіду роботи, що посилює актуальність дуального навчання [5].

Актуальність реалізації дуальної форми здобуття освіти у вищій школі пов'язана із включення роботодавців у процес підготовки спеціалістів, подоланням дисбалансу між вимогами ринку праці до кваліфікації молодих фахівців та рівнем їх освітньої підготовки [1].

I. Мухров визначає дуальне навчання як систему договірних відносин організаційної, педагогічної та економічної взаємодії освітньої організації з роботодавцями на основі соціального партнерства задля підготовки майбутніх фахівців відповідно до сучасних умовам праці та специфіки виробничого процесу; задоволення потреб виробництва в робочих кадрах і зростання професіоналізму кадрового потенціалу; задоволення потреб суспільства у забезпеченні зайнятості населення та розвитку ринку праці; задоволення потреб освітньої організації в розвитку конкурентоспроможності на ринку освітніх послуг [10].

Зарубіжні науковці А. Шельтен та Х. Штегман вважають, що підготовка фахівців за дуальною формою здобуття освіти активізує взаємодію та взаємозв'язок між навчальним середовищем та виробництвом, забезпечує своєчасне реагування на зміну його потреб і врахування тенденцій розвитку $[17 ; 20]$. 
Модернізація інтеграційних процесів в освіті передбачає осмислення дуальності як багатоаспектної методологічної категорії, що передбачає узгоджену взаємодію освітнього та виробничого середовища для підготовці висококваліфікованих фахівців за різними формами навчання.

Цінність професійних знань, одержаних в процесі дуального навчання, науковці С. Романов, Ю. Петров пов'язують із підвищенням вимог до результатів навчання, поєднанням освітнього процесу та його результату, створенням механізмів та інструментів взаємодії державного, приватного та соціального партнерства в освіті. Інтерес до впровадження дуального навчання вони обумовлюють тим, що в ході його реалізації відбувається задоволення інтересів як самих студентів, так і роботодавців. Науковці зауважують, що нині роботодавцеві потрібні висококваліфіковані фахівці, яких не потрібно «перенавчати» на підприємстві [11; 12].

Сучасному висококваліфікованому фахівцеві необхідно вміти швидко реалізувати набуті вміння та навички у професійній діяльності, ефективно працювати на рівні світових стандартів, бути професійно мобільним.

Ряд вчених (Р. Сафіна, І. Айтуганова, С. Корчагіна, Л. Самолдина) розглядають дуальну освіту в якості шляху вдосконалення практичного навчання, що реалізується за рахунок адаптації змісту освітніх програм 3 навчальних дисциплін до особливостей підприємств виконання майбутніми фахівцями завдань за конкретними замовленнями підприємств, залучення провідних фахівців підприємств до реалізації освітнього процесу.

Дуальна освіта створює реальну можливість для взаємозбагачення теорії та практики: теоретичних знань студентів та їх практичного застосування вже в студентські роки. Вона сприяє професійному становленню особистості, іiі розвитку та самовизначенню, формуванню готовності до виконання виробничих дій. За такої форми навчання набуття професійних компетентностей відбувається при виконанні виробничих дій, а розвиток особистості відбувається в умовах диференційованого навчання.

На аудиторних заняттях в умовах дуальної освіти у студентів формується висока мотивація до отримання знань, здійснюється залу- 
чення до професійної спільноти та корпоративної культури, студенти більш сумлінно, відповідально та усвідомлено відносяться до теоретичного навчання. Практична підготовка студентів відбувається безпосередньо на робочих місцях, що забезпечує більш успішне їх залучення до професійної діяльності. Позиція пасивного споживача навчальної інформації змінюється ініціативною позицією фахівця в умовах трудової діяльності, якому треба приймати рішення і нести за них відповідальність. За результати дуальної освіти відповідальні як навчальний заклад, так і підприємство, що на правах учасника такої форми освіти надало можливість студентам провадити практичну діяльність в реальних трудових умовах майбутньої професійної діяльності [4].

На сьогодні дуальна освіта набула визнання більш ніж у 60 країнах світу. Одним з лідері у підготовці висококваліфікованих кадрів вважають Європейський Союз, більшість країн якого мають дуальні заклади професійної та вищої освіти. Впровадження елементів дуальної форми здобуття освіти узгоджує традиційні та інноваційні форми навчання майбутніх фахівців, підвищує якість їх підготовки, встановлює відповідність між набутими професійними компетенціями та вимогами роботодавців.

Останнім часом дуальна освіта набуває все більшої популяризації й в Україні. Iї ефективність базується на поєднанні теоретичної підготовки у закладах вищої освіти та практичною підготовкою на базі суб' єктів господарювання (підприємствах, організаціях, установах).

\section{3. Історичні аспекти та нормативна база дуальної освіти}

У педагогіці поняття «дуальність» вперше було використане у 60-х роках XX століття у ФРН для позначення нової форми організації освітнього процесу, що передбачала паралельне навчання у закладі освіти та на виробництві. Дуальне навчання передбачало узгоджену взаємодію освітнього та виробничого середовища з метою підготовки фахівців певного профілю, тобто поєднувала теоретичне навчання у професійних школах та практичне - на підприємстві.

За основу дуальної системи навчання було покладено принцип взаємозв'язку теоретичного матеріалу з практичною складовою, що дозволяло студентам не лише знайомитися з майбутньою професій- 
ною діяльністю, але й засвоювати прийоми, удосконалити вміння та навички роботи на робочому місцях.

На початку 70-років дуальна освіта була впроваджена у вищих спеціалізованих навчальних закладах Німеччини (Fachhochschulen). Сучасне дуальне навчання займає важливе місце в системі професійної та вищої освіти Німеччини. Головне завдання дуальних закладів освіти - орієнтування на практичну складову освітнього процесу, тому деякі науковці називають такі заклади вищої освіти одно дисциплінарними.

Згодом дуальна форма навчання була експортована у більшість країн Європи, США, Канаду тощо.

З позиції сучасної педагогіки «дуальна освіта» використовується для опису навчального процесу, що одночасно реалізується у закладі освіти та на підприємстві, теоретичної підготовки у закладах освіти, що доповнюється професійно-практичними фазами на виробництві, організації підготовки фахівців на основі інтеграції навчальних закладів та підприємств-замовників кадрів, форми навчання тісно пов'язаної з практикою. Найбільш точним $є$ підхід науковців Т. Цибизової, О. Августан, О. Чернеги, які визначають дуальність як характеристику освіти, що передбачає побудовану на єдиних методологічних засадах злагоджену взаємодію освітньої та виробничої сфер для підготовки спеціалістів певного профілю в рамках різних організаційних форм навчання [16].

До основних чинників, що характеризують функціонування дуальної освіти належать: збільшення темпів технологічної революції, вплив виробництва на систему освіти, оновлення вимог до учасників ринку праці.

В Україні дуальне навчання починає набирати популярності, зараз його розуміння частково закріплено нормативними документами й актами. До усвідомлення необхідності системної модернізації освіти на засадах дуальності Україна прийшла нещодавно. Законодавчо поняття «дуальна освіта» було закріплено у ЗУ «Про освіту» (стаття $380,2017)$, де «дуальну освіту» визначено однією з форм здобуття освіти, що передбачає поєднання навчання осіб у закладах освіти 3 навчанням на підприємствах, в установах та організаціях для набуття певної кваліфікації. Більш деталізоване визначення поняття «дуальна освіта» подано у Концепції підготовки фахівців за дуальною формою здобуття освіти (від 19 вересня 2018 р. № 660-р.): спосіб здобуття 
освіти, що передбачає поєднання навчання у закладах освіти 3 навчанням на робочих місцях в установах та організаціях для набуття певної кваліфікації, на основі договору про здійснення навчання за дуальною формою здобуття освіти. Практичні аспекти реалізації цього процесу розглядаються у форматі здобуття освіти за вечірньою або заочною формою навчання, а також, у форматі практичної підготовки здобувачів вищої освіти денної форми навчання та здобувачів професійної (професійно-технічної) освіти на робочих місцях [8].

Згідно з Міжнародними стандартами кваліфікації ЮНЕСКО, дуальна система освіти - це організований навчальний процес реалізації освітніх програм, що поєднують часткову зайнятість на виробництві та навчання 3 неповним навантаженням в традиційній університетській системі навчання [19].

Європейський центр розвитку професійної освіти (Cedefop) визначає дуальну освіту як набуття знань і навичок через виконання завдання у професійному контексті, або на робочому місці.

У сучасних умовах модернізації освітянської галузі України, дуальна освіта інтегративна форма, що поєднує теоретичні та практичні аспекти навчального процесу.

Резолюція конференції «Дуальна освіта як відповідь на виклики, що стоять перед сучасною системою української освіти» (2014р., м. Київ) одним із основних завдань системи дуальної освіти визначає якість підготовки фахівців до потреб сучасного ринку праці та створення можливостей для закладів освіти надавати випускникам найсучасніші компетенції та кваліфікації.

Аналізуючи нормативно-правову базу з питання дослідження можна констатувати, що у рамках чинного законодавства (закони «Про освіту», 2017, «Про вищу освіту», 2014, Указ Президента України «Про національну стратегію розвитку освіти в Україні на період до 2021 року» від 25 червня 2013 р. № 344/2013, «Про зайнятість населення» № 2745-VIII, Державна національна програма «Освіта» («Україна XXI століття»), «Концепція підготовки фахівців за дуальною формою здобуття освіти» (розпорядження Кабінету Міністрів України від 19 вересня 2018 р.), Закони про працю) дуальна форма здобуття освіти розглядається як дієвий механізм трансформації та масовізації вищої освіти, що сприяє зміцненню практичної складової підготовки здобувачів вищої освіти. 


\section{4. Особливості організації дуальної форми здобуття вищої освіти}

Дуальна форма здобуття освіти є привабливою для економіки держави та виробничого сектора завдяки ряду причин:

- навчальні плани складаються з урахуванням пропозицій працедавців;

- роботодавці формують замовлення закладам освіти на основі потреб кваліфікованих виробничих кадрах, що володіють необхідними професійними знаннями, досвідом, соціальними й особистісними якостями. Це забезпечує підприємства молодими фахівцями (випускниками 3ВО), що не потребують тривалого адаптаційного періоду та готові до виконання своїх трудових функцій;

- майбутній працівник отримує реальну професійну підготовку на робочому місці на основі ефективних освітніх технологій; має можливість проходити виробничу практику на робочому місці й виконувати реальні професійні завдання. Тобто, після закінчення навчання у закладі освіти молодий фахівець (випускник 3ВО) підготовлений до виконання виробничих функцій та мотивований на трудову діяльність у колективі;

- під час практики студент перебуває у виробничому колективі, де засвоює норми та цінності корпоративної культури підприємства, на якому планує працювати після завершення навчання;

- зменшуються помилки кадрових служб у підборі персоналу, оскільки тривала виробнича практика студентів на підприємстві дозволяє виявити їх компетенції та здібності;

- скорочуються витрати підприємства на кадровий рекрутинг, оскільки переважна більшість випускників закладів освіти залишається на підприємстві, і роботодавцю немає потреби звертатися у кадрові агентства та служби зайнятості із заявками на вакантні місця;

- співпраця підприємства та закладу освіти в рамках дуального навчання дозволяє створити систему навчання персоналу підприємства, що спрямована на вирішення питань підвищення освітнього та професійного рівня співробітників.

Основною метою впровадження дуальної форми здобуття вищої освіти є усунення недоліків традиційних форм навчання, подолання невідповідності між теоретичною та практичною складовою процесу 
навчання, освітою та виробництвом, підвищити якість підготовки майбутніх фахівців з урахуванням вимог роботодавців.

Досягнення мети потребує вирішення наступних завдань: підвищення якості підготовки кадрів із урахуванням вимог потенційних роботодавців; оновлення професійних програм, форм та методів навчання; подолання відриву між теоретичною та практичною складовою освітнього процесу; посилення ролі працедавців у підготовці кваліфікованих кадрів, модернізація змісту освіти відповідно до вимог ринку праці.

Успішність впровадження дуальної форми здобуття освіти потребує визначення та характеристики принципів іiі реалізації та здійснення. На основі аналізу різних підходів до трактування принципів дуальної освіти, поданих у працях вітчизняних та зарубіжних науковців можна виокремити основні принципи дуальної форми здобуття вищої освіти:

- принцип дуалізму - визначає взаємозв'язок між закладом освіти, суб' єктом господарювання на основі співробітництва та підтримки;

- принцип системності - розкриває взаємозв'язки та взаємовідносини між учасниками дуальної системи, що забезпечують злагодженість їх взаємодії, цілісність завдань та змісту дуального навчання, взаємозв'язок теоретичної та практичної складової освітнього процесу за умов дуальності;

- принцип інтеграції - виражає єдність мети, завдань учасників дуального процесу, сутність діяльності освітнього та виробничого середовища в єдиному освітньо-виробничому;

- принцип відповідності змісту підготовки професійної підготовки фахівців перспективам розвитку відповідної галузі знань.

- принцип багатопрофільності - передбачає можливість одержання додаткової спеціальності в процесі дуального навчання;

- принцип мобільності освіти - визначає швидке реагування системи дуальної освіти на внутрішньо-системні та зовнішньо-системні впливи.

Дуальне навчання має логічну будову: від загально-професійного змісту до професійного та спеціалізовано-професійного. Воно передбачає якісну підготовку фахівців, що реалізується на основі навчально-науково-виробничої концепції та охоплює різноманітні аспекти підготовки молоді (самостійну роботу в умовах виробництва, залучення студентів до виконання виробничих завдань та професійних ситуації під час практичної підготовки). 
Дослідники Н. Морева, Г. Селевко, відзначають, що запровадження дуальної форми здобуття вищої освіти передбачає [9; 13]:

- активну участь студента в освітньому процесі;

- можливості використання теоретичних знань студентів у реальних виробничих умовах;

- подання знань у найрізноманітніших формах;

- підхід до навчання як до колективної, а не індивідуальної діяльності;

- акцент на практичній складовій освітнього процесу.

Навчання за дуальною формою здобуття освіти сприяє подоланню ряду проблем а саме:

- невідповідність змісту, структури та обсягів підготовки майбутніх фахівців основним тенденціям і перспективам розвитку виробництв;

- недосконалість механізмів соціального партнерства закладів вищої освіти, підприємств та роботодавців;

- невідповідність кадрового потенціалу закладів освіти вимогам та інноваційним завданням розвитку виробництва;

- невідповідність методичного та матеріально-технічного забезпечення освітніх установ завданням підготовки висококваліфікованих фахівців;

- недосконалість системи цільової підготовки фахівців для різних галузей високотехнологічних виробництв;

- недостатній рівень реалізації інноваційних методів та форм навчання;

- недостатню практичну зорієнтованість освітнього процесу при підготовці фахівців для конкретних галузей виробництва чи підприємств;

- відсутність системи незалежної оцінки (сертифікації) якості підготовки фахівця зі сторони роботодавців.

Основними умовами впровадження дуальної форми здобуття вищої освіти вважаємо [6]:

- наявність базових підприємств та установ, що є дуальними партнерами закладів вищої освіти;

- розробку програм взаємодії навчальних закладів, суб'єктів господарювання (підприємств, організацій, компаній, установ);

- введення стажування викладачів закладів освіти на підприємствах;

- залучення потенційних роботодавців та представників підприємств до реалізації освітніх програм.

Відзначимо ряд переваг дуальної форми здобуття освіти:

- наближення освітнього процесу до вимог виробництва; 
- підвищення цінності, соціальної значущості та практичної спрямованості освітнього процесу;

- орієнтування навчання на формування спеціальних фахових умінь та навичок майбутніх фахівців;

- підвищення мотивації студентів до набуття знань, необхідних для майбутньої професійної діяльності;

- покращення якості набутих студентами знань, вмінь та навичок;

- зростання зацікавленості керівників підприємств та установ у навчанні кваліфікованих кадрів;

- підвищення рівня фінансування закладів освіти та зміцнення їх матеріально-технічної бази за рахунок виробничого сектору;

- посилення інноваційної діяльність закладів освіти.

Дуальна форма здобуття вищої освіти навчання відрізняється від традиційного навчання рядом характеристик: зорієнтованістю на «навчання через досвід», рефлексією навколо виробничої діяльності здобувачів вищої освіти, зосередженістю навколо виробничих процесів, узагальненням знань через загальні та колективну діяльність, яка передбачає обговорення проблем, прийняття рішень.

Серед провідних особливостей дуальної форми здобуття вищої освіти можна визначити:

- налагодження партнерських взаємовідносин між сферою виробництва та закладами освіти;

- наявність привабливої для виробничого сектора складової освітнього процесу на основі «змішаного навчання» (частково у закладі освіти, частково - на базі підприємства чи установи);

- перехід від формального оцінювання знань, вмінь та навичок студентів до фактичного (визначеного роботодавцями);

- оцінювання результатів програм дуального навчання безпосередньо роботодавцями та провідними фахівцями підприємств;

- визнання набутих студентами практичних навичок та досвіду попереднього навчання при працевлаштуванні;

- участь студентів у практико-орієнтованих проектах, що відповідають потребам дуальних партнерів: здобувача освіти, закладу освіти, підприємства;

- індивідуальна підтримка студента закладом освіти та дуальним підприємством (організацією, установою); 
Запровадження дуальної форми здобуття освіти при підготовці здобувачів вищої освіти дозволяє подолати ряд недоліків традиційного навчання: недостатню мотивацію студентів до вивчення професійно-орієнтованих дисциплін, відсутність уніфікованих вимог до професійних компетенцій випускників зі сторони закладу вищої освіти та роботодавців, відокремленість освітнього процесу від реалій виробничого сектора та вимог працедавців, низький ступінь механізації технологічних процесів при проведенні практичних та лабораторних занять у закладах освіти.

Реалізація дуальної форми здобуття вищої освіти передбачає злагоджену діяльність та координацію освітнього процесу зі сторони державою, закладом освіти та суб'єктом господарювання (партнером закладу освіти від виробничого середовища, бізнесу).

Відповідальність за результат навчання розподіляється між підприємством та навчальним закладом. Це, в свою чергу, дозволяє рівномірно розподілити насиченість ринку праці, заповнити дефіцит у висококваліфікованих кадрах.

Порівняльну характеристику традиційної та дуальної форм здобуття вищої освіти подано у таблиці 1.

Таблиця 1

\section{Порівняльна характеристика традиційної}

та дуальної форм здобуття вищої освіти

\begin{tabular}{|l|l|}
\hline \multicolumn{1}{|c|}{ Традиційна форма здобуття освіти } & \multicolumn{1}{|c|}{ Дуальна форма здобуття освіти } \\
\hline $\begin{array}{l}\text { Зорієнтованість процесу навчання } \\
\text { на теоретичну складову }\end{array}$ & $\begin{array}{l}\text { Збільшення практичної складової } \\
\text { освітнього процесу }\end{array}$ \\
\hline $\begin{array}{l}\text { Теоретична та практична складові } \\
\text { освітнього процесу відокремлені }\end{array}$ & $\begin{array}{l}\text { Теоретична та практична складові } \\
\text { освітнього процесу є інтегрованими }\end{array}$ \\
\hline $\begin{array}{l}\text { Набуття практичних вмінь та навичок } \\
\text { відбувається під час проходження } \\
\text { технологічної (виробничої) практики }\end{array}$ & $\begin{array}{l}\text { Набуття здобувачами освіти } \\
\text { практичних вмінь та навичок } \\
\text { реалізується поетапно, на базі } \\
\text { суб'єктів господарювання }\end{array}$ \\
\hline $\begin{array}{l}\text { Програма різних видів практик є } \\
\text { частково наближеною до вимог } \\
\text { вимогам потенційних роботодавців }\end{array}$ & $\begin{array}{l}\text { Програма та завдання виробничої } \\
\text { практики є максимально наближеними } \\
\text { до вимог потенційних працедавців та } \\
\text { вимог ринку праці }\end{array}$ \\
\hline $\begin{array}{l}\text { Після закінчення навчання у закладі } \\
\text { вищої освіти, випускники потребують } \\
\text { тривалого періоду адаптації }\end{array}$ & $\begin{array}{l}\text { Випускники закладу освіти } \\
\text { не потребують «перенавчання» } \\
\text { на виробництві }\end{array}$ \\
\hline
\end{tabular}


Аналіз педагогічної літератури в рамках дослідження дозволив визначити основні етапи реалізації дуальної форми освіти у вищій школі:

- етап прогнозування - оцінка потреб ринку праці у фахівцях, здійснюється державними службами;

- організаційно-підготовчий етап, передбачає розробку національних стандартів вищої дуальної освіти, пошук підприємств - дуальних партнерів закладів освіти;

- етап проектування, результатом якого є розробка нових галузевих стандартів та дуальних програм;

- технологічний етап - впровадження дуальної освіти або ï елементів у роботі навчальних закладів, активне залучення спеціалістів підприємств та установ до навчального процесу; впровадження інноваційних освітніх технологій в навчальних процес для підвищення рівня підготовки студентів;

- рефлексивний етап - оцінка діяльності дуальних закладів освіти.

Дуальна форма здобуття освіти спрямована на удосконалення та оновлення змісту освітнього процесу, створення нового навчально-виробничого середовища. Учасниками дуального процесу є здобувачі вищої освіти, держава, суб'єкти господарювання (підприємства, організації, установи), заклади вищої освіти. Взаємодія учасників дуального процесу грунтується на взаємодії, взаємовигідному партнерстві та чіткому виконанні вимог дуальності [4].

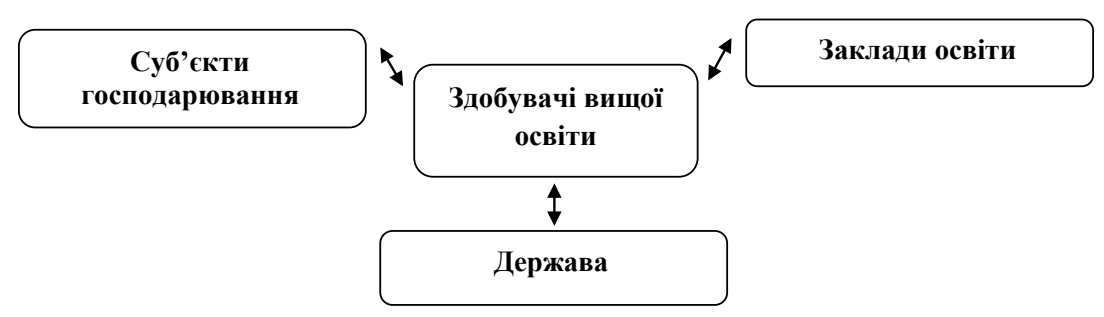

\section{Рис. 1. Взасмодія учасників освітнього процесу (за дуальної форми здобуття вищої освіти)}

Держава розробляє нормативне забезпечення дуального процесу, розробляє механізми співпраці між всіма учасниками дуального процесу, нормативно узгоджує їх взаємовідносини. 
Суб'єкти господарювання (в особі, керівників підприємств та установ, керівників структурних підрозділів, координаторів дуального навчання від суб'єкту господарювання, наставників дуального навчання) формують запит на підготовку спеціалістів певного профілю, ініціюють запровадження дуальної форми здобуття освіти у навчальних закладах, встановлюють комунікації із закладами освіти, разом із працівниками навчальних закладів визначають вимоги до професійної компетентності здобувачів освіти, призначають кураторів та наставників дуального навчання, контролюють якість практичної підготовки студентів на робочих місцях, забезпечують здобувачів освіти необхідним обладнанням та засобами праці, сприяють працевлаштуванню випускників закладів освіти.

Заклади освіти організовують та модернізують освітній процес відповідно до вимог суб'єктів господарювання, проводять інформаційну та роз'яснювальну роботу серед студентів щодо переваг дуальної форми здобуття освіти, розробляють дуальні освітні програми, забезпечують якісну теоретичну підготовку здобувачів освіти, налагоджують співпрацю з суб'єктами господарювання, спільно із представниками суб'єкту господарювання (координаторами, наставниками, керівниками структурних підрозділів підприємств) визначають зміст навчальних планів та освітніх програм, координують навчання студентів на робочих місцях.

Результативність впровадження дуальної форми здобуття освіти залежить від ряду критеріїв: розробки нормативно-правових документів, єдиної інформаційної бази даних для функціонування дуальної системи «держава - заклад освіти - суб'єкт господарювання», удосконалення змісту освітніх програм та навчальних планів, модернізації практичної частини освітнього процесу, єдиним вимогам до підготовки здобувачів вищої освіти зі сторони держави, роботодавців та навчальних закладів, забезпечення працевлаштування студентів на підприємствах.

\section{5. Висновки}

Проведене теоретичне дослідження дозволило виявити різні наукові підходи до реалізації дуальної форми здобуття вищої освіти. Серед перспектив дуальної освіти визначено налагодження чіткої вза- 
ємодії виробничого, освітнього середовищ та ринку праці з метою підвищення якості знань, практичних вмінь та навичок здобувачів вищої освіти, професійна зорієнтованість випускників закладів освіти на виробничий процес. Результативність впровадження дуальної освіти пов'язана з удосконаленням нормативно-правової бази, модернізацією освітнього процесу, залученням суб'єктів господарювання до освітнього процесу.

\section{Список літератури:}

1. Абашкіна Н.В. Принципи розвитку професійної освіти в Німеччині : монографія. Київ : Вища школа, 1998. 207 с.

2. Андрущенко В.П. Теоретико-методологічні засади реформування вищої освіти в Україні. Педагогічна газета. Академія пед. наук України. 2000. № 12(78) грудень. С. 1-2.

3. Беликов В.А. Философия образования личности: деятельностный аспект : монография. Москва, 2004. 357 с.

4. Галецкая М.Е. Теории мотивации и стимулирования трудовой деятельности. Молодой ученый. 2016. № 7. С. 813-816.

5. Гарифуллина Н.Ю., Мазаєва К.А. Рынок труда рабочих профессий: российские и международные тенденции. Проблемы современной экономики. 2014. № 3. С. 112-116.

6. Дудкін П., Дудкіна О. Формування та розвиток регіональних інноваційних структур як нова парадигма співпраці вищих навчальних закладів $\mathrm{i}$ бізнесу. Сочіально-економічні проблеми і держава. 2013. Вип. 2(9). С. 58-66.

7. Золотарева Н.М. Система подготовки кадров для инновационной экономики России. Инновационные проекты и программы в образовании. 2015. № 4. C. 24-27.

8. Концепція підготовки фахівців за дуальною формою здобуття освіти. URL: https://mon.gov.ua (дата звернення: 06.04.2019).

9. Морева Н.А. Технологии профессионального образования. Москва, 2008. $432 \mathrm{c}$.

10. Мухров И.С. Формирование профессиональной компетентности молодых квалифицированных рабочих автомехаников в системе начального профессионального образования в условиях социального партнерства : автореф. дис. ... канд. пед. наук : 13.00.08. Шуя, 2012. 24 с.

11. Петров Ю.Н. Дуальная система инженерно-педагогического образования - инновационная модель современного профессионального образования: монография. Нижний Новгород, 2009. 280 с.

12. Романов С.П. Развитие дуальной системы инженерно-педагогического образования в высшем учебном заведении : автореф. дис. ... докт. пед. наук : 13.00.08. Нижний Новгород, 2008. 49 с.

13. Селевко Г.К. Современные образовательные технологии : учеб. пос. для пед. вузов и ин-тов повышения квалиф. Москва, 1998. 256 с. 
14. Сушенцева Л.Л. Формування професійної мобільності майбутніх кваліфікованих робітників у професійно-технічних навчальних закладах: теорія і практика: монографія / за ред. Н.Г. Ничкало. Кривий Ріг : Видавничий дім, $2011.439 \mathrm{c}$.

15. Фалалеев А.Н. Государственное частное партнерство в инновационном развитии образования как ресурс региональной экономической системы. Вестник КГПУ им. В.П. Астафьева. 2015. № 4. С. 72-77.

16. Цибизова Т.Ю., Августан О.М., Чернега Е.В. Дуальная система образования как основа подготовки высококвалифицированных IT-специалистов на примере образовательных проектов «MAIL.RU GROUP». Современные проблемы науки и образования. 2017. № 5. URL: http://www.science-education.ru/ru/ article/view?id=26995 (дата звернення: 03.11.2019).

17. Шельтен А. Введение в профессиональную педагогику. Екатеринбург, 1996. $288 \mathrm{c}$.

18. Унайбаев Б.Ж. Дуальная модель профессионально-технического образования. URL: http://forum.eitiedu.kz/index.php/2012/01/04/dualnaya-model-ptobrazovaniya/ (дата звернення: 16.09.2018).

19. ЮНЕСКО: Недостатки образования способствуют кризису. URL: https://www.dw.com/ru/юнеско-недостаткиобразования-способствуюткризису/а-16307327 (дата звернення: 06.04.2019).

20. Stegman H. Das duale System im Blickpunkt: Structuren, Enwiclungen und zukuenftige Probleme in der betrieblichen Berufsausbildung in Materialien aus der Arbeitsmarkt und Berufsforschung. Nurnberg, 1986. № 9.

\section{References:}

1. Abashkina N.V. (1998). Pryntsypy rozvytku profesiinoi osvity v Nimechchyni [Principles of vocational education development in Germany]. Kuiv: Vyshcha shkola, $207 \mathrm{p}$.

2. Andrushchenko V.P. (2000). Teoretyko-metodolohichni zasady reformuvannia vyshchoi osvity v Ukraini [Methodological Principles for Reforming Higher Education in Ukraine]. Pedahohichna hazeta. Akademiia ped. nauk Ukrainy, no. 12(78), pp. 1-2.

3. Belikov V.A. (2004). Filosofiya obrazovaniya lichnosti: deyatelnostnyj aspekt: monografiya [Philosophy of personality education: activity aspect]. Moskva, $357 \mathrm{p}$.

4. Galeckaya M.E. (2006). Teorii motivacii i stimulirovaniya trudovoj deyatelnosti [Theories of motivation and stimulation of labor activity]. Molodoj uchenyj, no. 7, pp. 813-816.

5. Garifullina N.Y., Mazaeva K.A. (2014). Rynok truda rabochih professij: rossijskie i mezhdunarodnye tendencii. [The labor market of working professions: Russian and international trends]. Problemy sovremennoj ekonomiki, no. 3, pp. 112-116.

6. Dudkin P. (2013). Formuvannia ta rozvytok rehionalnykh innovatsiinykh struktur yak nova paradyhma spivpratsi vyshchykh navchalnykh zakladiv i biznesu [Formation and development of regional innovation structures as a new paradigm 
for cooperation between higher education institutions and business]. Sotsialnoekonomichni problemi i derzhava, no. 2, pp. 58-66.

7. Zolotareva N.M. (2015). Sistema podgotovki kadrov dlya innovacionnoj ekonomiki Rossii [Training system for the innovative economy of Russia]. Innovacionnye proekty i programmy v obrazovanii, no. 4, pp. 24-27.

8. Kontseptsiia pidhotovky fakhivtsiv za dualnoiu formoiu zdobuttia osvity. Available at: https://mon.gov.ua (accessed 06.04.2019).

9. Moreva H.A. (2008). Tekhnologii professionalnogo obrazovaniya [Vocational Education Technologies]. Moskva, $432 \mathrm{p}$.

10. Muhrov I.S. (2012). Formirovanie professionalnoj kompetentnosti molodyh kvalificirovannyh rabochih avtomekhanikov $\mathrm{v}$ sisteme nachalnogo professionalnogo obrazovaniya $\mathrm{v}$ usloviyah socialnogo partnerstva [Formation of professional competence of young skilled workers in car mechanics in the system of primary vocational education in the conditions of social partnership]. Avtoref. dis. ... kand. ped. nauk: 13.00.08. Shuya, $24 \mathrm{p}$.

11. Petrov Y.N. (2009). Dualnaya sistema inzhenerno-pedagogicheskogo obrazovaniya - innovacionnaya model sovremennogo professionalnogo obrazovaniya [The dual system of engineering and pedagogical education innovative model of modern professional education]. Nizhnij Novgorod, $280 \mathrm{p}$.

12. Romanov S.P. (2008). Razvitie dualnoj sistemy inzhenernopedagogicheskogo obrazovaniya $\mathrm{v}$ vysshem uchebnom zavedenii [The development of the dual system of engineering and pedagogical education in a higher educational institution]. Avtoref. dis. ... dokt. ped. nauk: 13.00.08. Nizhnij Novgorod, 49 p.

13. Selevko G.K. (1998). Sovremennye obrazovatelnye tekhnologii [Modern educational technology: textbook. pos. for ped. universities and advanced training institutions]: ucheb. pos. dlya ped. vuzov i in-tov povysheniya kvalif. Moskva, $256 \mathrm{p}$.

14. Sushentseva L.L. (2011). Formuvannia profesiinoi mobilnosti maibutnikh kvalifikovanykh robitnykiv u profesiino-tekhnichnykh navchalnykh zakladakh: teoriia i praktyka [Formulary of professional mobilization of Maybut Qualified Robotics at professional and technical initial mortgages: theory and practice]. (eds. Nichkalo N.G.). Institut profesiynotehnichnoyi osviti NAPN Ukrayini. Kriviy Rig: Vidavnichiy dim, 439 p.

15. Falaleev A.N. (2015). Gosudarstvennoe chastnoe partnerstvo v innovacionnom razvitii obrazovaniya kak resurs regionalnoj ekonomicheskoj sistemy [Public private partnership in the innovative development of education as a resource of the regional economic system]. Vestnik KGPU im. V.P. Astafeva, no. 4 , pp. $72-77$.

16. Cibizova T.Y., Avgustan O.M., Chernega E.V. (2017). Dualnaya sistema obrazovaniya kak osnova podgotovki vysokokvalificirovannyh IT-specialistov na primere obrazovatelnyh proektov MAIL.RU GROUP [The dual education system as the basis for the training of highly qualified IT specialists on the example of educational projects]. Sovremennye problemy nauki i obrazovaniya, no 5.

17. Unajbaev B.Zh. Dualnaia model professyonalno-tekhnycheskoho obrazovanyia URL. Available at: forum.eitiedu.kz/index.php/2012/01/04/dualnayamodel-pt-obrazovaniya (accessed 01.04.2019). 
18. Stegman H. (1986). Das duale System im Blickpunkt: Structuren, Enwiclungen und zukuenftige Probleme in der betrieblichen Berufsausbildung in Materialien aus der Arbeitsmarkt und Berufsforschung. Nurnberg, no. 9.

19. YUNESKO: Nedostatky obrazovanyia sposobstvuiut kryzysu [UNESCO: Disadvantages of education contribute to the crisis] Available at: www.dw.com/ ru/junesko-nedostatkiobrazovanija-sposobstvujut-krizisu/a-16307327 (accessed 01.04.2019).

20. Shelten A. (1996). Vvedenie v professionalnuyu pedagogiku [Introduction to Professional Pedagogy]. Ekaterinburg. (in Russian). 